\title{
Do The Fraud Triangle
}

\section{Components Motivate Fraud In Indonesia?}

\author{
Fauziah Aida Fitri ${ }^{1}$, Muhammad Syukur ${ }^{2}$ and Gita Justisa ${ }^{3}$
}

\begin{abstract}
In present day Indonesia, cases of frauds are rarely covered by the media. Even though some fraud might not be material enough to be detected, the motivation for conducting fraud exist, especially when the internal systems have some leakage. The fraud triangle and the Beneish model are two well-developed theories to understand the motivations for fraud and to detect earnings manipulation in a business. Therefore, this empirical research aims to examine the applicability of the fraud triangle components combined with the M-score from Beneish model. The investigation involves panel data from 270 non-financial companies listed on IDX (Indonesia Stock Exchange) during 2013-2015. The results approved that companies with detected fraud received (1) higher pressure on financial stability, leverage, and financial targets; (2) lower numbers of independent commissioners and more receivables from special (related) parties, and (3) more frequent changes to auditors.
\end{abstract}

JEL classification: $\mathrm{K} 40, \mathrm{~K} 41$.

Keyword: Beneish model, Indonesia, financial statement fraud, fraud detection, fraud triangle.

\footnotetext{
${ }^{1}$ Syiah Kuala University, Indonesia

${ }^{2}$ School of Management, Mae Fah Luang University, Thailand

${ }^{3}$ Syiah Kuala University, Indonesia
} 


\section{Introduction}

More ethical business practice is often requested by the public. Ethics should be a foundation for doing business to prevent unwanted results and triggering unethical behaviour. The absence of ethics in an organization can motivate fraud to occur (Adhariani \& Siregar, 2018). A deliberate failure to report financial information can be in the form of material misinterpretation (Nguyen, 2010), inappropriate income recognition and excessive asset recognition (Beasley, Carcello, Hermanson \& Lapides, 2000), negligence in the presentation of notes to the financial statement or other reasons for avoiding a bad image of the company (Agarwal \& Medury, 2014).

Fraud is dangerous to society and has the main economic impact among other types of crimes (Free, 2015). It brings huge losses, which have a significant effect on the capital market and lead to degradation of shareholder value, a decline in the value of shares, bankruptcy or liquidation, and leads to delisting from the national stock exchange (Beasley, Carcello, \& Hermanson, 1999). Therefore, fraudulent financial statements have become a severe concern for investors and other stakeholders.

Frauds in financial reporting can be identified with the fraud triangle approach proposed by Clinard and Cressey (1954) who suggested that financial fraud is caused by pressure, opportunity, and rationalization. A fraud (earnings manipulation) can also be detected by the Beneish Model, which was firstly introduced by Messod Beneish in 1999. This research links the Beneish model with the fraud triangle theory. Therefore, this study examines the applicability of the fraud triangle components combined with the M-score with results from the Beneish model. The result of this paper is expected to provide practical implications for prospective investors and stakeholders to detect fraud in their organization using the combination of both models.

\section{Literature Review}

Financial reporting fraud is a misstatement or elimination of amounts or disclosures that are intentionally carried out to deceive its users. The result of fraudulent financial reporting can increase the adverse impact on investors and global economic stability (Zhou \& Kapoor, 2011). Thus, fraud detection of financial statements is essential due to devastating consequences.

Fraud is often subtle at first, and increases if not detected. Thus, fraud detection plays an important role in assessing the risk of fraudulent financial reporting quickly and adequately (Srivastava, Mock, \& Turner, 2009). An approach that can be used for fraud detection is with the triangle fraud model. This model explains how one commits a fraud motivated by three components, namely pressure, opportunity and rationalization (Clinard \& Cressey, 1954). This model is constructed on the premise that cheating is a result of a combination of these three components.

To commit fraud, someone might be in financial stress or other types of pressure. Being under pressure will increase the likelihood of committing fraud (Suyanto, 2009; Aidafitri \& Arta, 2014). Some examples of pressures are financial needs, the need to perform better, work frustration, or company's target. Fraud can also happen because of the fraud-risk corporate cultures like bullying and top management greed. These 
cultures can be tackled down by increasing working ethos, encouraging proper behaviour, and well-tailored internal control (Schuchter \& Levi, 2016).

A pressure is claimed as a trigger factor of fraud that can direct the perpetrators to do the unethical behaviour (Ruankaew, 2013). Skousen et al. (2008) state that economic motives, either incentives or punishment, always appear in companies that commit fraud, such as profit target, growth maintenance, bonus deductions, poor performance evaluations, or even dismissal. These pressures invite a person to manipulate financial statements to make them look better than reality. Huang, Lin, Chiu, \& Yen, 2017) found that pressure is the strongest trigger among the three factors.

Fraud happens more often in companies with weak internal control systems (Manurung \& Hadian, 2013), poor security on properties, or unclear policies related to acceptable behaviour. These situations provide opportunities to take adverse action for insiders as they know the loopholes in the company. The perpetrator believes the weak internal control cannot catch them. Therefore, a well-built internal control system is needed to lower the opportunity for someone to commit fraud. Thus, fraud occurs because the actor has the opportunity to believe that his action will remain unnoticeable.

Rationalization is an attitude or character of someone who justifies fraudulent practices (Skousen et al., 2008). A perpetrator makes excuses as justification for their actions. For example, they rationalize that they only borrow the company's money, or no one was harmed by the action (Singleton \& Singleton, 2011). Research related to the fraud detection on financial report had been done with the concept of fraud triangle (Amara, Ben Amar, \& Jarboui, 2013; Lou \& Wang, 2009; Skousen et al., 2008), financial ratios (Dalnial, Kamaluddin, Sanusi, \& Khairuddin, 2014; Persons, 1995), as well as by linking earnings management with financial report fraud (Perols \& Lougee, 2011). There are contradictory results in detecting fraudulent financial statements with triangle fraud factors. Lou and Wang (2009) found that the three elements of the fraud triangle affect fraudulent financial statements. However, Suyanto (2009), Aghghaleh, Iskandar, and Mohamed (2014), and Diany and Ratmono (2014) found that financial reporting fraud was positively correlated with pressure and opportunity factors, but rationalization factors were considered difficult to test. Another contradictory result is also found in the study of Rachmawati \& Marsono (2014), which proves the fraud is influenced by opportunity and rationalization factors but not by the pressure factor.

Someone with deficient moral codes justifies illegal behaviours as acceptable (Lokanan, 2015). Perpetrators of fraud will seek various defensive mechanisms such as "no one is hurt" or "this is for the sake of our company". The research results of Chen \& Elder (2007), Rachmawati \& Marsono (2014), and Aidafitri \& Arta (2014) proved that the existence of rationalization affects the occurrence of fraud in financial statements. 


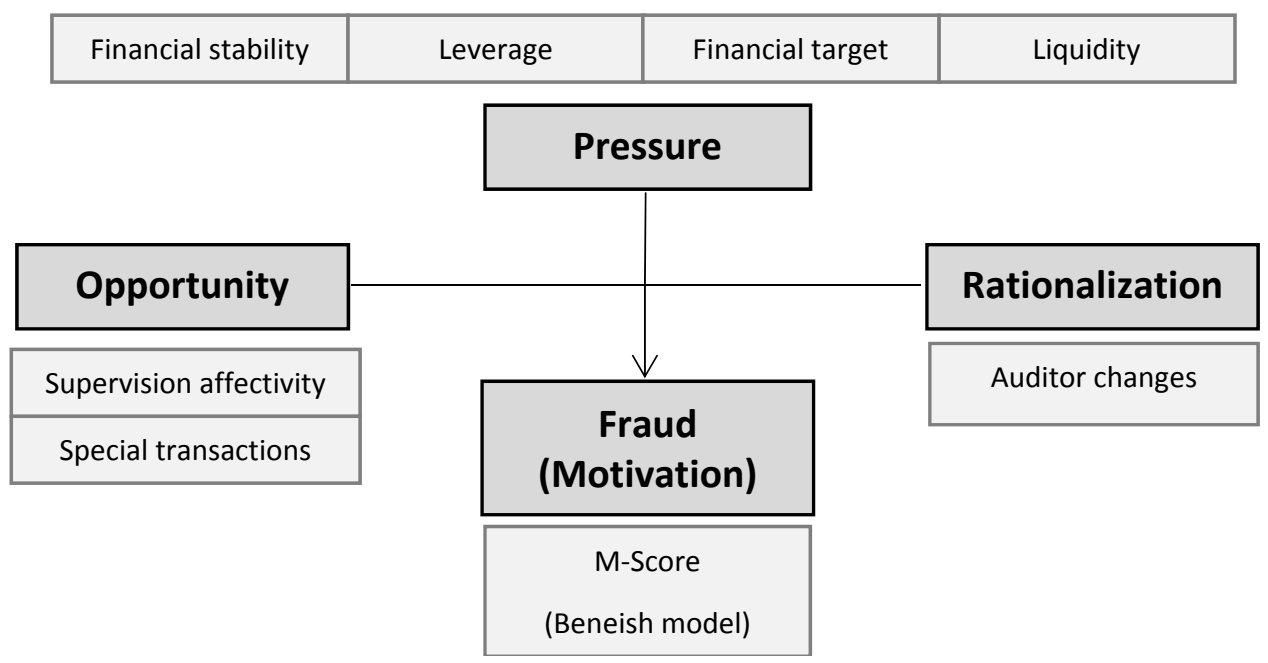

Figure 1 Theoretical framework

\section{Research Methodology}

\subsection{Population and Samples}

A population is the entire study object that consists of a number of individuals, either limited or unlimited (Sumarni \& Wahyuni, 2008:69). The population in this study is 381 non-financial companies listed on the Indonesia Stock Exchange (IDX). This study employs the purposive sampling method under some criteria that can be seen in Table 3.1 .

Table 1 Sampling criteria

\begin{tabular}{ccc}
\hline No & \multicolumn{1}{c}{ Criteria } & $\begin{array}{c}\text { Number of } \\
\text { companies }\end{array}$ \\
\hline 1. & non-financial companies consecutively listed on the IDX during 2013-2015 & 381 \\
$2 . \quad \begin{array}{l}\text { Companies that cannot access the annual report data and audited financial } \\
\text { statements in full successively on the IDX in 2013-2015 }\end{array}$ & $(25)$ \\
3. $\quad$ Companies that do not present financial statements in the form of rupiah & $(54)$ \\
4. Companies whose financial statements do not provide complete data & 270 \\
\hline Number of samples per year & 810 \\
\hline \multicolumn{2}{l}{ Number of observations $(270 \times 3$ years) }
\end{tabular}

Based on the results of the selection, there were 270 companies that met the criteria as research samples. The number of observations of this study for three years was 810 observations.

\subsection{Data Collection Techniques}

The secondary data is taken from the company's annual financial statements from 20132015. Secondary data is data obtained by researchers indirectly through intermediary media, which is the official website of the Indonesia Stock Exchange (www.idx.co.id). The data are financial statements of non-financial companies listed on the Stock 
Exchange in 2013-2015. To collect the data, documentation method is employed by studying, researching, and analyzing the company's financial statements.

\subsection{Variable Measurement and Operationalization}

\subsubsection{The Beneish's M-score}

To find out the companies that commit and do not commit fraud in financial statements are measured by the M-score of Beneish Model for earnings manipulation detection (Beneish, 1999). A company is deemed to commit frauds if the value of $M$ is greater than -2.22. If fraud is indicated, a company is given " 1 ", and it is given " 0 " if the company does not commit financial statement frauds. Later, these categories are examined through the fraud triangle.

$$
\begin{gathered}
M=-4,840+0,920 D S R I+0,528 G M I+0,0404 A Q I+0,892 S G I+0,115 D E P I- \\
0,172 S G A I+4,679 T A T A-0,327 L V G I
\end{gathered}
$$

With DSRI = Days' Sales in Receivables Index (ratio of days' sales in receivables versus prior year as an indicator of revenue inflation), $\boldsymbol{G M I}=$ Gross Margin Index (ratio of gross margin versus prior year), $A \mathbf{Q I}=$ Asset Quality Index (ratio of non-current assets other than plant, property and equipment to total assets, versus the prior year), $\mathbf{S G I}=$ Sales Growth Index (ratio of sales versus prior year), DEPI = Depreciation Index (ratio of the rate of depreciation versus prior year), $\boldsymbol{S G A I}=$ Sales, General and Administrative expenses Index (ratio of SGA expenses to the prior year), $\boldsymbol{T A T A}=$ Total Accruals to Total Assets (Total accruals are calculated as the change in working capital accounts other than cashless depreciation, $\boldsymbol{L} \boldsymbol{V G I}=$ Leverage Index (ratio of total debt to total assets versus prior year).

Since the introduction in 1999 to date, the Beneish model is practically used by academician and business people. It is the most comprehensive way to measure earnings manipulation in a company. Many models are better applied in highly complex economies, but the Beneish model is reliably applicable in emerging economies as proven by Kamal, Salleh, \& Ahmad (2016).

\subsubsection{The Fraud Triangle}

The fraud triangle consists of pressure, opportunity and rationalization factors that motivate criminals to commit fraud. These variables need proxies to make them into numbers. Pressure can be proxied into four types, namely financial stability, leverage (level of debt), financial targets, and liquidity (Nugraha \& Henny, 2015). Financial stability is measured by AGROW or asset growth, leverage by DR or debt ratio, financial target by ROA or return on assets, and liquidity by WCTA or working capital to total assets ratio (Persons, 1995). 
Table 2 Variable operationalization

\begin{tabular}{|c|c|c|c|}
\hline Variable & Proxy & Indicator & $\begin{array}{c}\text { Formula } \\
\end{array}$ \\
\hline \multirow[t]{4}{*}{ Pressure } & Financial stability & Asset growth & AGROW $=\frac{\text { Total asset }_{t}-\text { Total asse }_{t-1}}{\text { Total asset }_{t}}$ \\
\hline & Leverage & Debt ratio & $\mathrm{DR}=\frac{\text { Total Liabilities }}{\text { Total Asset }}$ \\
\hline & Financial target & Return on assets & $\mathrm{ROA}=\frac{\text { Earnings after tax }}{\mathrm{t}-1}$ \\
\hline & Liquidity & $\begin{array}{l}\text { Working capital to total } \\
\text { assets }\end{array}$ & WCTA $=\frac{\text { working capital }}{\text { Total Asset }}$ \\
\hline \multirow[t]{2}{*}{ Opportunity } & Affectivity of supervision & $\begin{array}{l}\text { Commissioners } \\
\text { independence }\end{array}$ & IND $=\frac{\text { number of independent commissioners }}{\text { number of the board of commissioners }}$ \\
\hline & $\begin{array}{l}\text { Transaction to special } \\
\text { parties }\end{array}$ & Special Receivables & SREC $=\frac{\text { Receivables on special parties }}{\text { Total receivables }}$ \\
\hline Rationalization & Auditor changes & Dummy variable & $\begin{array}{l}\text { Not changing auditor }=0 \\
\text { Changing auditor }=1\end{array}$ \\
\hline
\end{tabular}

Opportunity can be translated into two proxies, namely the effectiveness of supervision and transactions of special parties (Albrecht, Turnbull, Zhang \& Skousen, 2010). Managers who intend to manipulate reporting are likely to reduce the independent commissioner headcount. Therefore, the effectiveness of supervision is measured by the ratio of independent commissioners to the number of Board of Commissioners in the company (IND). Another proxy is the transaction with special parties, measured by dividing total accounts receivable on the special parties to the company's total receivables. Special parties are groups that have the ability to control another business in making financial and operational decisions.

Fraud is not only committed by employees, but also by people at the management level. To escape detection, management tends to change auditors frequently (DeFond, 1992). The relationship between management and auditors is management rationalization because auditor's observations have an effect on the risk and results of the audit, which raises concerns from management. In this study, the change in external auditors is proxied by Auditor Changes: if companies do auditor changes, then it is coded with " 1 " and companies that do not make auditor changes are coded as " 0 " (dummy variables).

After divided into "with fraud" and "without fraud", the samples are tested through the mean scores of all proxies. Finally, it is concluded whether companies with fraud get more pressure, opportunity, and rationalization compared to companies without fraud. Therefore, the hypotheses are:

H1. Companies with detected fraud are financially more stable;

H2. Companies with detected fraud are more leveraged;

H3. Companies with detected fraud have a higher financial target;

H4. Companies with detected fraud are more liquid;

H5. Companies with detected fraud are less supervised;

H6. Companies with detected fraud have more transactions with special parties; and H7. Companies with detected fraud change external auditor more often. 


\section{Research Results and Discussion}

Table 3 provides the calculation of the Beneish's M-score with its eight variables based on the financial information from the period 2013-2015. If the M-score is higher than 2.22, companies are detected committing fraud. After applying this rule, we found that 190 companies are assumed not committing fraud in the financial statements. It means that around 30 per cent of the samples is manipulating their statements.

Table 3 Beneish's M-score

\begin{tabular}{|c|c|c|c|c|c|c|c|c|c|c|}
\hline $\begin{array}{c}\text { DSR } \\
\text { I }\end{array}$ & $\begin{array}{c}\text { GM } \\
\text { I }\end{array}$ & $\begin{array}{c}\mathbf{A Q} \\
\mathbf{I}\end{array}$ & $\begin{array}{c}\text { SG } \\
\text { I }\end{array}$ & $\begin{array}{c}\text { DEP } \\
\text { I }\end{array}$ & $\begin{array}{c}\text { SGA } \\
\text { I }\end{array}$ & $\begin{array}{c}\text { TAT } \\
\text { A }\end{array}$ & $\begin{array}{c}\text { LVG } \\
\text { I }\end{array}$ & $\begin{array}{c}\text { M- } \\
\text { Score }\end{array}$ & $\begin{array}{c}\text { Conclusio } \\
\text { n }\end{array}$ & $\begin{array}{c}\text { No. of } \\
\text { companies }\end{array}$ \\
\hline 1.15 & 3.02 & 1.75 & $\begin{array}{c}1.9 \\
0 \\
4.5\end{array}$ & 1.62 & 3.96 & -1.17 & 1.82 & -7.01 & No fraud & 190 \\
\hline 3.67 & 1.88 & 3.40 & 5 & 5.34 & 3.72 & 0.66 & 1.62 & 6.26 & Fraud & 80 \\
\hline
\end{tabular}

To link the result of the Beneish model, the average scores of fraud triangle components are calculated for each group of companies: with fraud and without fraud, as shown in Table 3. The Beneish's M-score functions as the separator for the samples.

Table 4 Mean value of fraud triangle components

\begin{tabular}{rrrcc}
\hline & \multicolumn{1}{l}{ Variables } & & $\begin{array}{c}\overline{\mathbf{x}} \\
\text { No fraud } \\
\mathbf{N}=\mathbf{5 7 0}\end{array}$ & $\begin{array}{c}\overline{\mathbf{x}} \\
\text { With fraud } \\
\text { N=240 }\end{array}$ \\
\hline Pressure & Financial stability & AGROW & 0.074 & 0.128 \\
& Leverage & DR & 0.501 & 0.703 \\
& Financial target & ROA & 0.044 & 0.068 \\
Opportunity & Liquidity & WCTA & 0.222 & 0.174 \\
& Supervision affectivity & IND & 0.372 & 0.341 \\
Rationalisation & Special transaction & SPREC & 0.135 & 0.275 \\
& Auditor changes & AC & 0.094 & 0.166 \\
\hline
\end{tabular}

Table 4 shows the mean value of indicators to measure pressure, opportunity, and rationalisation for both companies with and without fraud. It is shown that the companies with fraud receive more pressure on financial stability (AGROW $=0.128$ ), level of debt $(\mathrm{DR}=0.703)$, and financial target $(\mathrm{ROA}=0.068)$ compared to companies without detected fraud which receive less pressure on financial stability (AGROW = 0.074 , level of debt $(\mathrm{DR}=0.501)$, and financial target $(\mathrm{ROA}=0.044)$. It is contrary to the finding of Dechow, Ge, Larson, and Sloan (2011), which found that return on assets is lower in companies with fraud. However, it is concluded H1, H2, and H3 are accepted, but $\mathrm{H} 4$ must be rejected.

Companies with detected fraud are less supervised by of independent commissioners $(\mathrm{IND}=0.341)$ and have more transaction with special parties $(\mathrm{SPREC}=0.275)$ compared to companies without fraud that are more supervised by independent commissioners $($ IND $=0.372)$ and have less special transactions $($ SPREC $=0.135)$. This reflects that management from companies with detected fraud tried to limit the numbers of independent commissioners to prevent detection of fraud. These companies also had more transactions with organizations that have a special relationship with the company. It is easier to plan a crime with these special organizations. Therefore, H5 and H6 are accepted. 
Fraud companies also change external auditors more often $(\mathrm{AC}=0.166)$ compared to companies without detected fraud $(\mathrm{AC}=0.094)$. External auditors are public auditors that have no relationship and no interest in a business, so the professional judgment (audit opinion) is based on the real findings during the audit process. Being audited from different auditors every year enables managements to hide proofs.

Table 5 Hypothesis checking result

\begin{tabular}{|c|c|c|}
\hline No & $\begin{array}{c}\text { Hypothesis } \\
\end{array}$ & Conclusion \\
\hline H1 & Companies with detected fraud are financially more stable. & Accepted \\
\hline $\mathrm{H} 2$ & Companies with detected fraud are more leveraged. & Accepted \\
\hline H3 & Companies with detected fraud have a higher financial target. & Accepted \\
\hline $\mathrm{H} 4$ & Companies with detected fraud are more liquid. & Rejected \\
\hline H5 & Companies with detected fraud are less supervised. & Accepted \\
\hline H6 & Companies with detected fraud have more transactions with special parties. & Accepted \\
\hline $\mathrm{H} 7$ & Companies with detected fraud change external auditor more often. & Accepted \\
\hline
\end{tabular}

\section{Conclusions, Implications, and Limitations}

\subsection{Conclusions}

This empirical study is to check the applicability of the fraud triangle model by matching the concept with the Beneish model. The results show that companies with fraud receive more pressure on financial stability, leverage, and financial target, bigger opportunity due to the less independent commissioner and more transactions with special parties, as well as more rationalization showed by changing auditors more often compared to companies without detected fraud.

\subsection{Implications}

This study has implications for prospective investors and stakeholders to be able to understand the components that might cause fraudulent actions in financial reporting. Therefore, they can better detect fraud and improve decision making. For scientific implications, this research can be used as a reference to develop future research in the perspective of triangle fraud and the Beneish model.

\subsection{Limitations}

Future researchers might extend the fraud model to add social factors that can motivate fraudulence. Cieslewicz (2012) and Mui and Mailley (2015) mentions some societal factors such as philosophical and religious tradition, culture, social norms, socioeconomic conditions and political status. Future studies can also examine the significance of the difference in the fraud triangle components between companies with fraud and companies without fraud.

\section{References}

Adhariani, D., \& Siregar, S. V. (2018). How Deep Is Your Care? Analysis of Corporations' "Caring Level" and Impact on Earnings Volatility from the Ethics of Care Perspective. Australasian Accounting, Business and Finance Journal, 12(4), 43-59. https://doi.org/10.14453/aabfj.v12i4.4

Agarwal, G. K., \& Medury, Y. (2014). Internal auditor as accounting fraud buster. The 
IUP Journal of Accounting Research \& Audit Practices, 13(1), 7-29.

Aghghaleh, S. F., Iskandar, T. M., \& Mohamed, Z. M. (2014). Fraud risk factors of fraud triangle and the likelihood of fraud occurrence : Evidence from Malaysia. Information Management and Business Review, 6(1), 1-7. https://doi.org/10.1108/17506200710779521

Aidafitri, F., \& Arta, N. (2014). Fraud in government agencies an goverment official's behaviors: Evidence from the press. In Enterpreunership and creative Economy in Global Competitiveness, The 2nd International Conference on Business and Economics. Padang: Universitas Andalas Padang.

Albrecht, C., Turnbull, C., Zhang, Y., \& Skousen, C. J. (2010). The relationship between South Korean chaebols and fraud. Management Research Review, 33(3), 257-268. https://doi.org/10.1108/01409171011030408

Amara, I., Ben Amar, A., \& Jarboui, A. (2013). Detection of Fraud in Financial Statements: French Companies as a Case Study. International Journal of Academic Research in Accounting, Finance and Management Sciences (Vol. 3). https://doi.org/10.6007/IJARAFMS/v3-i3/34

Beasley, M. S., Carcello, J. V., Hermanson, D. R., \& Lapides, P. D. (2000). Fraudulent Financial Reporting: Consideration of Industry Traits and Corporate Governance Mechanisms. Accounting Horizons, 14(4), 441-454. https://doi.org/10.2308/acch.2000.14.4.441

Beasley, M. S., Carcello, J. V, \& Hermanson, D. R. (1999). Fraudulent Financial Reporting: 1987-1997 An Analysis of U.S. Public Companies Research. Dana, 167.

Beneish, M. D. (1999). The Detection of Earnings Manipulation. Financial Analysts Journal, 55(5), 24-36. https://doi.org/10.2469/faj.v55.n5.2296

Chen, K. Y., \& Elder, R. J. (2007). Fraud risk factors and the likelihood of fraudulent financial reporting: Evidence from statement on Auditing Standards No. 43 in Taiwan (Working Paper). Taiwan.

Cieslewicz, J. K. (2012). The Fraud Model in International Contexts : A Call to Include Societal-level Influences in the Model. Journal of Forensic \& Investigative Accounting, 4(1), 214-254.

Clinard, M. B., \& Cressey, D. R. (1954). Other People's Money: A Study in the Social Psychology of Embezzlement. American Sociological Review, 19(3), 362. https://doi.org/10.2307/2087778

Dalnial, H., Kamaluddin, A., Sanusi, Z. M., \& Khairuddin, K. S. (2014). Accountability in Financial Reporting: Detecting Fraudulent Firms. Procedia - Social and Behavioral Sciences, 145, 61-69. https://doi.org/10.1016/j.sbspro.2014.06.011

Dechow, P. M., Ge, W., Larson, C. R., \& Sloan, R. G. (2011). Predicting Material Accounting Misstatements*. Contemporary Accounting Research, 28(1), 17-82. https://doi.org/10.1111/j.1911-3846.2010.01041.x

DeFond, M. L. (1992). The Association Between Changes in Client Firm Agency Costs and Auditor Switching. Auditing: A Journal of Practice \& Theory, 11(1), 16-31.

Diany, Y. A., \& Ratmono, D. (2014). Determinan kecurangan laporan keuangan : Pengujian teori fraud triangle. Diponegoro Journal of Accounting, 3(1953), 1-9.

Free, C. (2015). Looking through the fraud triangle: a review and call for new directions. Meditari Accountancy Research, 23(2), 175-196. https://doi.org/10.1108/MEDAR-02-2015-0009

Huang, S. Y., Lin, C.-C., Chiu, A.-A., \& Yen, D. C. (2017). Fraud detection using fraud triangle risk factors. Information Systems Frontiers, 19(6), 1343-1356. https://doi.org/10.1007/s10796-016-9647-9

Kamal, M. E. M., Salleh, M. F. M., \& Ahmad, A. (2016). Detecting financial statement 
fraud by Malaysian public listed companies: The reliability of the Beneish MScore model. Jurnal Pengurusan, 46, 23-32.

https://doi.org/10.17576/pengurusan-2016-46-03

Lokanan, M. E. (2015). Challenges to the fraud triangle: Questions on its usefulness. Accounting Forum, 39(3), 201-224. https://doi.org/10.1016/j.accfor.2015.05.002

Lou, Y., \& Wang, M. (2009). Fraud Risk Factor Of The Fraud Triangle Assessing The Likelihood Of Fraudulent Financial Reporting. Journal of Business \& Economics Research, 7(2), 61-78. https://doi.org/10.19030/jber.v7i2.2262

Manurung, D. T. H., \& Hadian, N. (2013). Detection fraud of financial statement with fraud triangle. Proceedings of 23rd International Business Research Conference, 978-1. https://doi.org/10.13140/RG.2.1.1736.6806

Mui, G., \& Mailley, J. (2015). A tale of two triangles: Comparing the fraud triangle with criminology's crime triangle. Accounting Research Journal, 28(1). https://doi.org/10.1108/ARJ-10-2014-0092

Nguyen, K. (2010). Financial statement fraud: Motives, methods, cases and detection. Universal Publishers.

Nugraha, N. D. A., \& Henny, D. (2015). Pendeteksian laporan keuangan melalui faktor resiko,tekanan dan peluang (Berdasarkan press release OJK 2008-2012). E-Journal Akuntansi Trisakti, 2(1), 29-48. https://doi.org/10.25105/jat.v2i1.4830

Perols, J. L., \& Lougee, B. A. (2011). The relation between earnings management and financial statement fraud. Advances in Accounting, 27(1), 39-53. https://doi.org/10.1016/j.adiac.2010.10.004

Persons, O. S. (1995). Using financial statement data to identify factors associated with Fraudulent Financial Reporting. Journal of Applied Business Research, 11(3), 38. https://doi.org/10.19030/jabr.v11i3.5858

Rachmawati, K. K., \& Marsono. (2014). Pengaruh faktor - faktor dalam perspektif fraud triangle terhadap fraudulent financial reporting (Studi kasus pada perusahaan berdasarkan sanksi dari Bapepam periode 2008-2012 ). Diponegoro Journal of Accounting, 3(2), 1-14.

Ruankaew, T. (2013). The Fraud Factors. International Journal of Management and Administrative Sciences (IJMAS), 2(2), 1-5.

Schuchter, A., \& Levi, M. (2016). The Fraud Triangle revisited. Security Journal, 29(2), 107-121. https://doi.org/10.1057/sj.2013.1

Singleton, T. W., \& Singleton, A. J. (2011). Fraud Auditing and Forensic Accounting, Fourth Edition. Fraud Auditing and Forensic Accounting, Fourth Edition. https://doi.org/10.1002/9781118269183

Skousen, C. J., Smith, K. R., \& Wright, C. J. (2008). Detecting and predicting financial statement fraud: The effectiveness of the fraud triangle and SAS No. 99. Advances in Financial Economics, 13(99), 53-81. https://doi.org/10.1108/S1569-3732(2009)0000013005

Srivastava, R. P., Mock, T. J., \& Turner, J. L. (2009). Bayesian fraud risk formula for financial statement audits. Abacus, 45(1), 66-87. https://doi.org/10.1111/j.1467-6281.2009.00278.x

Sumarni, M. dan, \& Wahyuni, S. (2008). Metodologi Penelitian Bisnis. Yogyakarta: Andi.

Suyanto. (2009). Fraudulent financial statement Evidence from statement on auditing standard no. 99. Gadjah Mada International Journal of Business, 11(1), 117-144. https://doi.org/10.22146/gamaijb.5539

Zhou, W., \& Kapoor, G. (2011). Detecting evolutionary financial statement fraud. Decision Support Systems, 50(3), 570-575. https://doi.org/10.1016/j.dss.2010.08.007 